\title{
RELIGIOUS EDUCATION BASED MULTICULTURALISME IN VIEW OF MUHAMMAD FETHULLAH GULEN
}

\author{
M. Khoirul Hadi al-Ash'ari \\ Blambangan Islamic College of Banyuwangi, Indonesia \\ E-mail: hadiari701@gmail.com
}

\begin{abstract}
Research is a research-based Library Research, which is based on the reading of the literature on Fethullah Gulen, this research wants to reveal about the importance of education based on the multicultural, multicultural education in this paper pick-tentak Fethullah Gulen figure that gives an integral view of religion and public education, in this paper will show some results of the first study, that multicultural education is important in the effort menghalu radicalism, Fethullah Gulen's second try to give a new reading of Islamic religious education toward a more Humanist and egalitarian, the third understanding of multicultural education is taken from the understanding of the Qur'an.
\end{abstract}

Keyword: education, Gulen, Multiculturalisme

\section{A. Introduction}

The riots that occurred in recent years in various regions in Indonesia, such as the case of Situbondo (1998), and which to this day still continues to flare up as the case of Ambon, basically it is result of conflict between different religions. Each side claimed that he was the most truthful, while the other side was wrong. Perceptions that the distinction is a bad, a terrible thing, it has deeply ingrained in the soul of followers of religions.

As the result of that conflict is the misery of all the parties, warring or who do not know anything. Basically as a result of the 
conflict is the loss of a thorough in various parties. Poor people once again become the victim and must bear the consequences caused by the conflict.

As a result of the conflict or unrest in a region eventually spread to other areas, which are still the region and outside the region are different. The flare-up of the condition in a region, such as the existence of inter-religious conflict could provoke another area because of the emotional bond being so strong, the bond as fellow believers. Something similar happened in the area of Mataram, Lombok (February 2000) when Muslims did grand tablig to respond the condition of Muslims in Ambon which ended with riots in the form of destruction of places of worship and educational facilities of Christians. Irrespective of provocateurs and others who used to be the scapegoat in every "chaos", which is clearly that religious emotion do not have sufficient control so that it easily persuaded to perform various acts of anarchy.

The collapse of the New Order regime provided fresh air to the nature of democracy in Indonesia. The freedom that so long was behind the iron curtain finally opened, but freedom does not mean freedom without rules and norms. Various kinds of riot and vigilantism wrapped "paper" socio-economic issues, politics with nuances of ethnicity, religion, race and groups (SARA) is quite condensed in various parts of Indonesia for example: riots in Poso, Sampit and other riot. Differing views, ethnicity, race and religion are sometimes used as an excuse for self-defense. This phenomenon very be pitied and it shows that the people have lost their identity as a human being that humane and virtuous. Respect for diversity has not been respected.

Education is an agent of change in culture (cultural broker) for the surrounding community, like it or not Islamic education must make improvements. This is a heavy duty, on one side modern life requires intellectual ability to respond positively and creatively to the changes that occur without having escape from the substance and the principles of universal religion. Plurality of Indonesian society, on the 
other hand, also demanded religious attitudes inclusive and tolerant. By using the contextual paradigm of classical thinking, these attitudes are positive and creative response to change and inclusive religious attitude. There are some world leaders who engaged in education based on religious tolerance still very few one of them is Muhammad Fethulleh Gulen.

The great spiritual personage from turkey, by his inner circle called the Hoceefandi, are among some Muslim leaders in the world who are very concerned with Islamic education in his pearl of Wisdom, written by M Fathulleh Gulen, he said someone was able to build his family well, then he was able to build another big things well. In the book Religious Education of the Child also describes how to educate children to obtain high spiritual spirit is by giving an example of the closest namely parents. With all that, every individual as a parent will do best.

Candidates for Parent will try to continue the better, and the child will be the best generation, then Islam will return victorious on this earth. He was trying to reconcile the traditional values of Islam with modern life and science M. Fethullah Gulen believed that we need to explain Islam through science and scientific fact, because most people just accept these reasons. Because the materialization and anti-religiosity seek to use science to defy religion and consider their ideas more practical than it should. So, we can do argument with them. The successful of Fathulleh Gulen was educating young generation in the sciences and religion so it can resolve them from ignorance and fortify them with diseases of spiritual. When he was teaching, Fathulleh Gulen focused on love, faith, and prophet of Sunnah. in addition he also explained about criteria of ablutions and the basic principles of hizmat, serving the community of the key concepts of Sufism like taqwa repentance, ascetic, Iklhas, muqrabah, trust, tawadu 'gratitude, charity, patience, and ma'rifah.

Inside the figure of clerics plenary was born in Erzuruuan in 1938 is illustrated blend of Sufi figure, rational thinker, poet and messenger. The message of peace. Activities in the area of social and 
religious that has begun since the 1960s made the most respected figures in Turkey. Messages of peace have distributed throughout Asia, Europe and America. He manifested in itself harmony and tolerance. Gulen (2002: VXII-xviii) reminded people about an inclusive view of Islam that is based on the concept of Sufism and love of humanity and that Islam is always in harmony with modernity, democracy and progress. The book by inspiring ideas be realized with using a new and fresh approach to understanding Islam. His concern to education and human welfare were embodied with his efforts in establishing various educational institutions all over the world, he never felt tired the social and spiritual activities.

One of the emphatically belief is if you want to master the future, separate them from knowledge, because through knowledge can be overthrown. He is totally self-perpetuating to solve social problems, and he believes that justice only come and be maintained through adequate universal of education. In the societies, in order to respect the rights of others. For this purpose he continually pushed the elites of society and local leaders, industrial and business community in the community to support a quality education for those who need (Gulen, 2002: VXIIII).

One of the Gulen's privileges was the ability to interpret the normative values of Islam that was born during the Apostle and growing in Salaf era into the context of modern life. He was also able to put Islam as a value that totally contrary to the good of the universal values that practiced by the international community. did anything during this for the Ulama is considered taboo, such a dialogue and cooperation with figures of different Agam (Kalyonsu, 2008: 2). All of Gulen movement did very in appreciation by the public fighters for democracy, peace, gender and so on. In this paper will discuss how Fethullah Gulen interpretation of the verses pruralisme which related to religious of education. How the implementation of religious of education based multukultiralisme and its relevance to the deradicalization of Religion? all of this will discuss in this paper. 


\section{B. Biography of Muhammad Fethullah Gulen}

Muhammad Fethullah Gulen was born in 27 April 1941 in Korucuk, a small village in Anatolia population are only about 60-70 heads of the family and he was still alive. This includes the village of Hasan Kale district (Pasinler) in the province of Erzunrum. Gulen's ancestors came from Ahlat District (khalat) that historic and included in the province of Blitis that located at the foot of the mountain. In ancient times, the descent of Rasullullah Saw, Nothing emigrated to Blitis to save themselves from the tyranny of rulers Daula Umayyads and Abbasids. In that place they became moral mentor for the community so the spirit of Islam penetrated into the psyche of Turkish tribes who lived in the region.

Fethullah Gulen was born in the family that very religious and spirit to the Islamization of the couples who very obedient. Syamil Agha, his grandfather figured that reflected the attitude of earnestly and steadfast in religion, a figure that had very strong bond with her grandchildren, Fethullah Gulen.

Gulen's father named Ramzi Gulen, during his life, Ramzi Gulen known as highly knowledgeable personal, procedures, and intelligent. Had never Ramiz Gulen missed his time to do something useless and he was also famous for its generous and gentle. Meanwhile Muni'sah Hanim was a figure grandmother who was a figure in his community as a devout worship. With many figures were great family the little Gulen was born and raised in the midst of the family, since the beginning of the little Gulen learned Qur'an to His mother. He could recite and finish Al-Qur'an nicely within a month . More interesting was the time to study for the Little Gulen who directly taken care by his own mother was in the middle of the night and early morning. One of the traditions that still existed in Gulen's family was that Gulen's house has been a place for visiting scholars in the neighborhood, it was almost every day, so that the little Gulen was very familiar with staying in touch communicated with the scholars since youth. 
According to Gulen, one of the great scholars that effected on the principle of his life Muhammad Lutfi Scholars who came from Alvar, and the arrival of Muhammad Lutfi always waited by the little Gulen to listen the useful advices and inspiration that he taught when Gulen was a kid the little Gulen, Meanwhile the language skills and other knowledge getting the little Gulen from his father which is actually a man possessed of knowledge especially relevant with the history of the Prophet Muhammad. And love were he transmitted to little Gulen to invest in individuals of Prophet Muhammad in the soul of little Gulen.

The education that pursued by small Gulen was very complicated, Moreover since the disaster struck his family, and it greatly affected the heart and soul of Gulen so it made him follow the path a dervish or Sufi. However Gulen did not forget the importance of the other sciences for example theology, philosophy of science, general science and other sciences. Since the beginning he has studied Islamic sciences and general sciences in formal schools in the city of Erzurum. Inside it dwelt some great scholars, one of whom was Osman Bektasi Gulen taught a variety of science such as sciences Nahwu, Balaghah, jurisprudence, Usul Fiqh, and Aqaid. Gulen also followed the scientific assessment that conducted by Said Nursi, and also he studied specifically about the Risale-I Nur that inside taught the movements of said Nursi which very comprehensive and modern. And at the same Gulen also remained focused in the general scientific assessment of such as physics, astronomy, chemistry, and biology, and he had a very wide insight relating to the science.

That is no less interesting than the figure of was that reading books that he studied wide dimension without limits, from the figure of Jean Paul Sartre, Herbert Marcuse, and various works of philosophers of existentialism. And many books that also gave a strong influence in understanding the reference philosophy in the east and west that mastered (Ghulen, 2012: 1203-2). At the relatively young age around twenty years has wandered to do risahlah scientific and headed in various cities in Turkey, one of the purposes city that 
Gulen came was the city of Edirne, which became the city gates of Turki from the west. In the the city at the same time, Gulen became a high priest in the mosque Uc Serefelli. During he became the high priest of the mosque Gulen's zhuhud at the same time, Gulen were excellent After approximately two years as a priest in the the mosque of Ederne, he followed the compulsory military, after compulsory military he returned to ederna and became a teacher in the a madrasa Tahfidh Tahfidh Qur'an and Islamic Pazari Kestane Kawaizh. At the same time, Gulen toured in the all regions of Anatolia. Starting from 1970 at the same time, Gulen did anything else such as "AlMukhayyamat" ie when at the same time, Gulen vowed to devote himself to solemn in the way of Allah and humanity committed by educating people to obedient and persevere to God. And through this path Gulen began to teach the moral values into their soul, in front of his followers he looked like a knight that aroused their spirits and had strong views that could penetrate the recesses of their hearts who grieving.

Precisely on March 12, 1971, Fethullah Gulen was arrested by the Turkish government on charges of plotting maker by changing socio-political foundation adopted by Turkey. Exploit the observance of Turkish society towards Islam. Fortunately accusations and jail were valid for six months, because all the accusations were being leveled to Gulen not proven. After the slump that occurred, Gulen doing a scientific treatise, by doing scientific lectures, among the alumni of the Higher education, teachers, entrepreneurs and a variety of other professions. Applying what is taught by Gulen to devote to religion, Mankind and the nation. It was also the forerunner from the movement Hizmet Movement (waiter for the community that came from thinking of Fethulleh Gulen Hocefendi), which also much involved people who did not expect the profit with remaining in compliance with the laws of turkey, people are involved this movement eventually established the public schools and special schools to enter the college. And after the Soviet Union collapsed, this movement became into a movement that developed and diffused 
throughout the world especially in Central Asia. When a lot of another Muslim trapped in a matter of "Dar al-Islam" and "Dar al-Harb" Fethullah Gulen with his movement was very loud when he asked about the relation with the State of Rebuplik Turkey, and emphatic opinions that said by Gulen was that Turkey was "Dar al -Hidmah "and opinions in said by Gulen he proved with solemn not only in Turkey but all over the country in the world. The motto love and patience embedded in the minds of their followers Hizmet Movement they worked to educate humanity selflessly. So that happened was the real thing that was built by Gulen strongly felt by them the communities were all over world.

In addition Gulen also concentrated with movement of dialogue among nations to do the movement of inter-religious tolerance and religious leaders around the world. This movement began from Turkey and continued throughout the world. This movement reached its peak when Gulen invited officially in a conference that conducted at the Vatican where Gulen met with Pope John Paul II at the invitation of the supreme leader of the Roman Catholic Church. During that time Gulen also had a lot of work produced by Gulen, Gulen was figure who multitalented, because with broad insights and master of Da'wah and also had many followers (Ghulen, 2012: 1206-1210). As for the works of Gulen was the first, thousands of cassettes and videos that contained speeches and lectures that delivered in various occasions. Secondly, archives of Getirgidi Tereddutler. (4 vol. has emerged as books and answered the questions about Islam). Third, Kalbin Zumrut Tepeleri, (translated as Key Concepts in The Practice of Sufism in Indonesian edition published by Sri Scissors with titles Sufi Secret Keys). Fourth, Cagve Nesil. (The new era and generation of the Young). Fifth, Sonzuz Nur (2 Vol. Prophet Muhammad: aspects of life in the Indonesian edition published by Republika entitled Eternal Light Muhammad. Pride of Mankind). Sixth, Olcu Ve Yolda Isiklar. (4 Vol. has emerged as a jewel of Wisdom), the seventh, the Book ve Sunnet Prespektinde Kader. (Contain teaching and explanation of Fate, translated into 
Indonesian entitled Qadar). All books was published in Turkey the amount of 70,000 thousand copies there were also some works of Gulen that translated into the various languages. Among them are English, Germany, Indonesian, Arabic, Kurdish, Russia, China, Bulgaria, France, Netherlands, Spain, Italy, Japan, and Portugal.

Although Gulen never met with Said Nursi directly, but he was a faithful follower of Said Nursi, so the movements that was built by Gulen was influenced by the thought of Said Nursi . the differences of Fundamental of Gulen's movement and Said Nursi is the social area, a Yakuz Hakan (2003: 3) states "one that is more paxis oriented and seeks to transforms society and its institutions by expanding circles of sympathizers early supporters. The Gulen Movement has been transformed by its own outcome (its teacher, school and media outlets) and by the means it uses to achieve its goal ".

It is also in the field of nationalism, globalization and the free markets. If Nursi has opened discussion of Intellectual Muslims, While Gulen more inspired people with improving education. Gulen engaged in the field of social transformation and used neo-liberal economics with political conditions that evolved. By his scholar character and intellectual that exist in hisself. The final goal from this movement was to sharpen the personal awareness of a Muslim. Deepen the sense of togetherness in the society, strengthening social civic groups through education and networking. And reach a peaceful solution in solving social and psychological problems that exist in society (Yakuz, 2003: 19).

\section{The Multicultural Religious Education In view of Fethullah Gulen}

Gulen developed the integrative education in developing education, the most emphasized is an Islamic piety and clung to the science. Contrast to the general understanding of Muslims and growing at that time. Muslims believe that the science of Knowledge "western" solely belongs to the west. Gulen was through movement education and want to create a better Muslim generation in the future by conducting 
simboisis Religion mutualism between science and general science. Gulen Declare "as For Man, Real life is accompanied by Knowledge and education: Those neglating learning and teaching, if it may be alive, can be Considered as dead because The aim's of human creation consists of seeing, understanding, and teaching the learned Knowledge to other "(Yakuz, 2003: 48). This generation that Gulen expected to sit in the government so that they had a true vision to reach people's welfare.

Gulen argues that the fundamental problem in the Muslim community nowadays is a matter of education, this condition makes the Muslims far behind for it to awake the Muslims of the slump is by spread knowledge to the development of quality education. With this education will get an important contribution to develop the world community (Abdullah, 2010). Quality education is one of the critical ways that must be traveled by Muslims. Gulen tried to develop three important elements in science, first, Natural sciences, second, the social sciences, and the third, the science of religion. These three dimensions are important to invest in the Muslim community. Gulen believes that education modern that occurred in the west should be balanced with science ethics and morals, while Islam on the contrary, moral runs but science stagnate. Gulen tries to combine both these problems in the field of advancement to the people, with combining between western progress with moral values and ethics of Islam. Gulen also states that religion and science are not two-dimensional that walk alone but two complementary poles. View of the world (world view) that based on religion can provide a comprehensive understanding and explanation to support and gives meaning to secular education that was developed in the west. Gulen invites students to rationalize that there is a clear link to the relation between religion and science. The purpose of education according to Gulen (2003: 25) is to achieve happiness in this world and hereafter. Gulen's view is almost equal or intertwined with the view of Imam Alghazali. Alghazali (nd: 14) states: "And verily, you know that the results of science is closer to Allah, connect and close to the height of the 
angels, so it in the Hereafter, The world is Glory, Patience and Respect habitual."

The phrase indicated that Fethullah Gulen and alGhazali very concerned about the life of the world and the hereafter as well. Thus the creation of joint happiness in the world and in the Hereafter, from here can be understood that according to these two great thinkers a Muslim should not be looking at the world in one side only are only world or the hereafter, but should pay attention of both.

This indicated that when Gulen was looking at a single science and there is one in Islam. According to , faith and Islam must be complementary and Sciences also, the world view (world view) that based on religion can provide comprehension and comprehensive explanation to support and give meaning to education secular, good education based on Gulen is when students can connect events between the outside world with a personal practice, Gulen rejected the religion as a blind faith, to understand religion without science, he saw needing to reconcile faith and underestimated the legitimate sense of the thing that often occured in the Islamic world.

Spirit of multiculturalism education was taught by Gulen is derived from the concept of Islam rahmatan lil Alamin. according to Gulen, rahmatan lil Alamin concept is the basic concept of education that interesting and should be applied for Muslims this modern era, in this consept there are three major themes that always echoed by Gulen, first, love; The second study inter-religious dialogue; and third, tolerance education.

First, the concept of love or education charity, the meaning of rahmatan rahmatan lil Alamin as a love can be read as a whole in his work are entitled Toward a Global Civilization: Love and Tolerance. Gulan (2004) wrote the book with a theme expressed what exactly is the essence of life, what exactly should be taught to students about the essence life, he thinks, life is a major grace that given by God or God Almighty. And eternal and true life is the life in the hereafter. We can worth living if we obey God he sent the Prophet and lowering the 
scriptures with a feeling of love and pity to all Humans in the Qur'an it is delivered by the Lord in a letter al-Rahman:

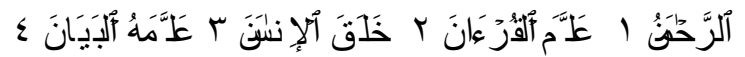

1. The Beneficent Allah,2. Taught the Quran.3. He created man,4. Taught him the mode of expression. (QS. Ar-Rahman 1-4)

God's love in this letter can be found inside the Prophets one of them is the Prophet Muhammad. Prophet Muhammad as a prophet of the end times his affections are felt until the second by second to His people. In history we can prove that Prophet besides being very affectionate to Muslims but also to the hypocrites, with did not severe punishment if he did good and would teach for Muslims. They are released when they wanted to ask for protection to Muslims they protected in Islamic literatures often called infidels zimmi, when these values are scaled in the eyes of education actually Prophet taught His people that education of love and affection fellow human beings especially fellow Muslims themselves is the recommended so that in education especially education Multicultural love and affection is the concept that the most powerful tool in creating a generation of mutual affection and love among people of other religions and to the people with same religion. Love-based education is missing from today's world of modern education.

In view of Gulen, this verse wanted to explain that although in local pagans there are still people who follow the Prophet. Then, that area will remain safe. And God always opens the door Taubat for those who are in error. Personally Prophet Muhammad also really love children, whenever he saw a child crying, he sat beside her and shared feelings, he was more feeling pain of a mother for her child than the mother's own.

To the children he liked hugging and kissing them. Additionally Prophet also exemplifies about the importance of education of love for the worlds, in one hadith the Prophet Said: Love the earth so that heaven will love you "when Sa'ad Ubadah fell ill, the Prophet. Saw at his house, he cried and said: "God did not punish 
because tears or sadness, but he was punished because of this", and $\mathrm{He}$ pointed to his tongue. See the description of this hadith that according to Gulen Prophet taught us to not hurt Nature then set in educating in giving lessons to students by showing examples of the form of love for the Universe. Gulen is a person who can articulate Islam with the reality so that the souls of multiculturalism become growing and developing in the thoughts and ideas. According to Gulen religious dialogue in approach have a strong foundation in Islam,

Multiculturalism education of while departing from beautiful dialogue system and the confidence of fellow human beings that different beliefs. According to Gulen, Islam teaches peace and safety (Islam is derived from the word silm and Salama) Islam is a religion that teaches security, salvation and peace, is included in the principle of self Muslims when praying to God, they severed all relationships of existing with World. Fervently to God in obedience. But after finished praying they returned into the world to spread peace in the world, this is exactly recommended by the Prophet Muhammad. "Give good greeting to someone that you know or not" (HR. Abu Daud). With that basis, the Gulen strongly opposed all forms of terrorism in the name of Islam and he taught the idea of reconciliation of safety and security and tolerance in the midst of learners, and it is highly unlikely Islam has a doctrine of terrorism, because according to Gulen, if we get back the source of Islamic teachings and its history, clearly shows Islam is far from violence, cruelty, especially blind fanaticism. Islam is a religion of forgiveness, forgive and develop tolerance. So in this context, the doctrine of Jihad in Islam should be interpreted appropriately. Gulen states "Jihad can be a Matter of self-defense or of removing obtackles between God and Human Free Choice, our History is full of examples that show how this principles has been implemented a life" in this context Gulen emphasized that the Qur'an which talked about jihad is only appropriate for which particular context that is not generalized in the context of life today, some irresponsible people have used the verses of the Qur'an as the basis of 
them doing acts of terror that undermine the entire relationship of Muslims with other communities in the world.

At the level of practice, Gulen tried to explore the dialogue early on a basic level until the level larger, starting from education and schools that were built by Gulen's foundation Gulen to enter the curriculum peace tolerance love of compassion and behavior that was peace, at the level of the International Gulen ever held in February 1998 Fethullah Gulen went to vatikan and met with Pope Jonh Paul II, the ruler of the Vatican, that action was protested by many parties because they thought that Gulen humbled himself and degrading Islam in front of Other Religions. he had a different view, according to Gulen Humility is part of Islamic teachings, he was as a direct consequence from expression of the faith of a people to God. One of the interesting statement that made by a Catholic researcher to Fethullah Gulen:

I am not a member of " the Gulen movement" nor am I a Muslim, but I have had the opportunity to visist many of these school in varios countries and to extensively interview the administrative and teaching staffs, as well as Muslim and nonmuslim students, their parents and non muslim educators in those locales. When I read the ideals expressed in Gulen's writings, I do fine them effectively practiced in the lives of those in the movement. These are cleary modern people, well trained in the secular sciences, but with a genuine conceren for spiritual an humane values. They seek to communicate thes balues to students by their own comportement, they offer a first-rate education that brings together the latest technological advances with character formation and high ideals. The Gulen's Schools in My opinion, are The most effective proof of the validity of Gulen's effort to reconcile modernity with spiritual values, they are ine of the fascinating and promosing educational efforts going on in the word at the present time (Michel: 356).

While the educational materials Fethullah Gulen has two educational orientation that education has two directions namely 
education of world and the hereafter, in the contemporary period there are many schools that founded was inspired by the thought of Fethullah Gulen, Gulen believed that ignorance is the enemy of the public, and in order to minimize this problem he suggested to the people around him to open schools and educational institutions that established in the science of Modern which promote morals and morality, Gulen believed that the education system in Turkey does not offer the knowledge and values to develop a holistic individual learners, therefore Gulen dreamed to build private schools where students given the opportunity to be taught with science in the modern, at the same time they also educate with morals, ethics and love for the human beings. As for the characteristic from multiculturalism Gulen schools were two orientations that established ie orientation sense and love for Muslims as explained in the philosophical foundations of education Multicultural Fethullah Gulen. Fethullah Gulen thought that:

The Spririt of Madrasa education and the spirit of modern education can come together, They can make a new marriage, and the mind's radiance and the hert's light can be reunited, whit their union and integration, the student zeal will take wing and fly (Journalist: 46).

The values of madrasah education and the values of modern be collaborated will probably produce a new formulation, of light minds and hearts of light can be united, with unity and integration, learners will have wings and fly. Learning model like this is very good for forming the personality of the learner, every day the students are guided to explore the science, nobility of heart and sincerity morals, therefore learning is not only doing in the class but also in the dorm.

According to Gulen curriculum multiculturalism should be disseminated and taught to learners, in the implementation of the schools that Fethullah Gulen established in the various countries have a the motto "Righ environment for learning" emphasized to the curriculumthat based development of skills, knowledge, morals as its 
mission so that a life of love of affection in education to develop multicultural education will be realized. Fethullah Gulen states:

Religion and science are not two different things, but two things are essential and complement each other. Learning Science and religion should be equally regarded as Worship activities, science is something that try to observe and study the verses of Allah Almighty Kauniyyah Therefore religion will unite in order to have insisted on the proper Science (Ergeni, 2005: 237).

Meanwhile the special features possessed by multiculturalism Gulen schools are: First, tried to form students were excel in the field of science and character, also stood out in the social field (multiculturalism), emotional and physical performance for example in the field of art. Second, Student Help garner realistic objectives that foster a fondness of Reviews their language and culture, and a keen awareness of Reviews their surroundings to help them becoming tolerant, open-minded and respectful toward other cultures in a multicultural context of the region and the international sphere. Third, an integration between the national curriculum and international curriculum were strengthened with a curriculum developed by the foundation were inspired by Gulen Fethulal internationally oriented curriculum, the relationship of curriculum with the purpose of education is closely and could be described clearly. Fourth, character building and morals were through moral education and development and current science teaching. Fifth, Training for Trainers, training of teachers and staff, including the sharing of ideas between teachers motivation regularly held also the curriculum development always controlled. Sixth, To Participate in the education Endeavors by making students know that they are they are the most beloved creations of god and to comprehend the exact meaning of the spirit of unity, helping appreaciating to each other with care. We believe that this the only way to reach for humanity and the real happiness, this vision clearly in line with the concept of education that oriented by Gulen, that education is not only aim to make them getting a better life, further education is to awaken us to God with all the power and 
the importance of morality, spirituality of life in guiding the students to serve the country and nation, be an educational institution leading in the world with a superior system.

The concept of Gulen's schools will give birth to the nation's generation of reliable which is not only knowledgeable but also immoral has the quality of leadership, that remarkable is how school tries to form students who are not only excel in science and character, but stand out is the emotionally, social and physical performance such as in the field of art. This is idealized view is that education system holistically in it will build a great generation.

While the relevance of education in Indonesia is, that the foundation Gulen has already established the educational institutions in Indonesia, before "Gulen Movemnet" coming in Indonesia, Indonesia has a soul multiculturalism in the presence of Gulen it becomes very helpful for building education or educational institutions that fits with the spirit of Indonesia in the form spirit of multiculturalism.

\section{Conclusion}

In this study we can conclude that there are three outcomes to be achieved first, are able to know the biography of Fethullah Gulen and his movement style of thinking that Gulen was built. Secondly, that the views of Fethullah Gulen in understanding the education is very comprehensive, Gulen try to integrate between religious education and general education the a larger context, the schools were built by Gulen has always taught the value of compassion tolerance and the values that indicate Islam was peaceful. Third, that philosophically Gulen gives multicultural education foundation with a variety of approaches are very religious, with the values of multiculturalism that strong and make them agents disseminator of Islam peaceful in the middle of the International Community. Fourth, his relevance to education in Indonesia is there some Gulen's education in Indonesia multiculturalism that characterizes education in Indonesia. 


\section{References}

Abdullah, Amin. (2010). "Fethullah Gulen and Characther Education in Indonesia". Makalah di presentasikan dalam The Significanse of Education for The future: The Gulen Model of Education. Jakarta. 19-20 Oktober.

Agai, Bekim, (2003). "Gulen Movement's Islamic Ethic of Education" dalam M. Hakan Yakuz dan John L-Espito (ed) Turkish Islam and the Seculer State: The Gulen Movemnent. New York: Syracuse University Press.

Al-Ghazali, Imam. (tt). Ihya 'Ulumuddin. Istambul: Cile Yayinevi.

Ergene, M. Ernest. (2005). Gulen Hareketinin Gelenegin Moderen Caga. Tanikligi: Yeni Akademi Yayinlari.

Gulen, Muhammmad Fathullah. (2002). Kehidupan Rasul Allah Muhammad SAW. Jakarta: Murni Kencana.

Istambul: Nil Yayinlari. (2003) Olcu Veya Yodalki Isiklar. (2004). Toward a global

Civilization: Love and Toleranci. New Jersey: The Light, Inc.

Kalyoncu, Mehmet. (2008). A Civilion Response to Etho-Religius Conflict: The Gulen Movement in Southeast Turkey. New Jersey: Light Inc.

Yakuz, M. Hakan. (2003). Islam in Public Sphere: The case of The Nur Movement, dalam M. Hakan Yakuz dan Jonh L. Espito (ed). Turlish Islam and Secular State: The Gulen Movement. New York: Syracuse University Press.

Wartini, Atik. (2014). "Perdamaian dalam pandangan M Quraish Shihab. Makalah. Pasca Sarjana UIN Yogyakarta. 